\title{
Tradisi Palang Pintu masyarakat Betawi dalam konteks budaya Islam
}

\author{
Riyan Anugerah Wibowo, Lutfiah Ayundasari* \\ Universitas Negeri Malang, Jl. Semarang No. 5 Malang, Jawa Timur, Indonesia \\ *Penulis korespondensi, Surel: lutfiah.ayundasari.fis@um.ac.id
}

Paper received: 03-01-2021; revised: 15-01-2021; accepted: 30-01-2021

\begin{abstract}
Writing this article aims to find out about the tradition of the Palang Pintu Mayarakat Betawi community in the context of Islamic culture. The method used is descriptive qualitative research. Many people in Indonesia already know about various traditions that are spread in various regions. One such tradition is the doorstop which comes from the Betawi tradition. The doorstop has become a mandatory tradition in Betawi community grooming events. The Betawi community is a society that upholds the value of diversity and equality of both local and foreign people without distinguishing the ethnicity and culture from which they come. Palang Pintu is a Betawi culture in one of the traditional wedding processions and over time it is used for weddings and welcoming guests. Islamic values contained in it make this tradition have elements of Islamic culture which until now is still a tradition for some Betawi people based on the description above, the author takes the formulas: 1) Explaining the Background of the Cross Door Tradition, 2) Explaining the Process of Implementing the Cross Tradition door, 3) explain the traditional values of the doorstop.
\end{abstract}

Keywords: Palang Pintu; Betawi; Islam

\begin{abstract}
Abstrak
Penulisan artikel ini bertujuan untuk mengetahui tentang tradisi Palang pintu Mayarakat Betawi dalam konteks budaya Islam.metode yang digunakan adalah penelitian Kualitatif deskriptif. Banyak orang di Indonesia sudah tahu tentang berbagai tradisi yang tersebar di berbagai wilayah. Salah satu tradisi tersebut adalah Palang pintu yang berasal dari adat Betawi. Palang pintu menjadi suatu tradisi yang wajib dalam acara mantenan masyarakat Betawi. Masyarakat Betawi adalah masyarakat yang dimana menjunjung tinggi nilai keberagaman dan kesamaan sesama etnis baik lokal maupun mancanegara tanpa membedakan suku dan budaya dari mana mereka berasal Palang Pintu adalah suatu kebudayaan khas Betawi dalam salah satu prosesi adat pernikahan dan pada seiringnya waktu digunakan untuk pernikahan dan penyambutan tamu. Nilai-nilai islami yang terkandung di dalamnya menjadikan tradisi tersebut memiliki unsur kebudayaan islam yang sampai saat ini masih menjadi tradisi bagi sebagian masyarakat betawi. Berdasarkan uraian diatas, penulis mengambil rumusan: 1) Menjelaskan Latar belakang Tradisi Palang Pintu, 2) Menjelaskan Proses Pelaksanaan Tradisi Palang pintu, 3) Menjelaskan Nilai-Nilai Tradisi Palang pintu.
\end{abstract}

Kata kunci: Palang Pintu; Betawi; Islam

\section{Pendahuluan}

Kebudayaan adalah sebuah pandangan hidup dari beberapa individu dalam bentuk sikap, nilai religius, dan makna-makna simbol yang tanpa sadar mereka terima secara langsung melalui proses pembicaraan dan pengulangan dari generasi yang lama ke generasi yang baru (Liliweri, dalam Paramita, 2018). Salah satu kelompok yaitu masyarakat Betawi memanglah memiliki bermacam ragam budaya yang mengandung nilai moral kehidupan. Salah satunya adalah pelaksanaan akad mantenan atau pernikahan masyarakat Betawi. Pada pernikahan adat Betawi, sebelum dilaksanakan prosesi acara ada salah satu pertunjukan budaya yang bernama palang pintu. Palang pintu merupakan suatu kebudayaan yang dipakai dalam acara 
pagelaran pernikahan masyarakat Betawi yang pada kegiatannya adalah pertarungan antara jawara Betawi dari mempelai Laki-laki melawan jawara Betawi dari mempelai wanita dengan adegan silat.

Masyarakat Betawi adalah masyarakat yang dimana menjunjung tinggi nilai keragaman dan kesamaan sesame etnis baik lokal maupun mancanegara tanpa membedakan suku dan budaya dari mana mereka berasal. Budaya Betawi memegang unsur dimana bersandarkan makna nilai religius serta nilai kebudayaan. Kearifan lokal masyarakat Betawi umumnya terwujud di dalam suatu peristiwa serta perilaku mereka yang senantiasa yang menjadi ciri khas masyarakat Betawi. Dijelaskan bahwa masyarakat Betawi gemar dengan tradisi gotong royong, sehingga dalam pelaksanaannya masyarakat Betawi ini memiliki etnik yang unik di masyarakat khususnya daerah Ibu Kota tersebut.

Kendati demikian Masyarakat Betawi mengetahui dengan seni bela diri serta keahlian mengaji dapat membuktikan bahwa orang Betawi memiliki filosofi hidup yang agamis sejak kecil. Semenjak kecil sudah diperkenalkan dengan berbagai macam nilai-nilai pedoman dalam Alqur'an yang menjadikan isi kandungannya dengan berperilaku serta bertutur kata yang baik sehingga memiliki karakter yang sopan santun yang baik. Silat diajarkan kepada anak muda bagaikan wujud melindungi keluarga serta lingkungannya dari bermacam berbagai kendala.

\section{Metode}

Metode yang digunakan dalam penelitian ini menggunakan metode penelitian kualitatif deskriptif. Konsep dalam metode ini menguraikan secara deskriptif tentang pemanfaatan situs sebagai sumber kegiatan belajar, dengan langkah - langkah penelitian yang meliputi beberapa tahapan. Tahapan yang pertama adalah eksplorasi studi kepustakaan atau literatur. Eksplorasi awal menggunakan pendekatan metode penelitian sejarah (Anggito \& Setiawan, 2018).

Proses untuk dapat menguraikan dan mendeskripsikan tentang Makna dari Tradisi "Palang Pintu" ini dapat dilakukan. Adapun tahapan yang diperlukan untuk penulisan sejarah ada lima tahap yaitu: pertama pemilihan topik, kedua pengumpulan sumber tertulis, ketiga sumber verifikasi atau kritik ekstern dan kritik internal guna untuk mengetahui yang baik digunakan untuk penulisan, keempat interpretasi atau menganalisis tulisan berdasarkan sumber yang dipilih, kelima penulisan makalah karena dilakukan secara sistematis sesuai dengan aturan.

\section{Hasil dan Pembahasan}

\subsection{Latar Belakang Palang Pintu}

Palang Pintu merupakan salah satu tradisi kebudayaan masyarakat Betawi dengan beradu silat dalam serangkaian acara pernikahan antara manten laki-laki dan perempuan. Palang pintu sebagai salah satu rangkaian acara pernikahan adat Betawi yang nantinya akan diadakan berbagai macam pagelaran seperti seni music, adu pantun, adu silat, dan pembacaan shalawat serta pembacaan ayat suci Al -Qur'an.

Pada upacara pernikahan adat Betawi, Palang pintu termasuk dalam salah satu rangkain acara tersebut. Palang Pintu mempersembahkan Pantun dan Pencak Silat dalam pertunjukannya yang disajikan dalam upacara pernikahan adat Betawi. Palang Pintu itu sendiri memiliki arti dimana Digunakan sebagai syarat bagi Laki-laki yang akan menikah. Calon Laki- 
laki Betawi memiliki dua hal yang harus ada jika ingin menikahi calon wanita, yaitu mampu Silat sebagai Laki-laki yang akan melindungi istri dan anak-anaknya dan dapat mengaji karena Laki-laki akan menjadi imam untuk upacara keluarga mereka. Dengan miliknya Silat, pengantin Laki-laki mampu mengalahkan Laki-laki yang merupakan Palang Pintu dalam keluarga pengantin wanita. Hanya saja dalam acara tersebut mempelai Laki-laki digantikan oleh salah satu Laki-laki yang menjadi wakilnya sehingga kemampuan pencak silatnya tidak teruji dan banyak yang tidak paham bahwa ada syarat lain yang harus dikuasai oleh sang mempelai Laki-laki yaitu menjadi bisa membaca (Siregar \& Irtawidjajanti, 2019).

\subsection{Proses Pelaksanaan Tradisi Palang Pintu}

Sebagai kebiasaan dalam masyarakat Betawi, anak Laki-laki dalam rumah tangga Betawi diajar Pencak Silat dan pengajian dalam kehidupan sehari-hari, mereka akan berlatih di lingkungan rumah mereka. Ketika seorang anak Laki-laki telah dewasa dan siap menikah, kedua kemampuan ini melekat dalam dirinya. Hanya saja kebiasaannya sudah hilang, kampung Betawi yang hilang membuat banyak campur aduk ragam kehidupan etnis masyarakat DKI Jakarta. Pada saat yang sama, praktik Silat hilang di rumah mereka. Sedangkan amalan pengajian dilakukan sesuai dengan kebiasaan orang tua di rumah masing-masing. Dalam akad nikah Betawi, diungkapkan Chaer (2012) berpendapat bahwa terdapat rangkaian acara berupa Akad Nikah, Malam Kondangan, Ngebesan, Malam Pengantenan (malam pengantin), Ngintip Penganten (intip pengantin), Nengokin penganten (kunjungan pengantin).

Sejarah pada cerita Betawi zaman dulu yang dijumpai jawara main pukul di hampir setiap daerah yang berada di Kawasan masyarakat betawi. Zaman dulu masyarakat Betawi memiliki kisah dimana bila seseorang bepergian ke kampung lain, yaitu para Jagoan disana akan menguji kemampuan para pengunjungnya yang terkait hingga saat ini dengan nama Silat. Hal tersebut kemudian diaplikasikan oleh masyarakat Betawi di dalam prosesi adat pernikahan untuk menguji keseriusan pihak laki-laki.

Roswita (2013) mengatakan bahwa palang pintu memiliki beberapa unsur di dalamnya terdiri atas satu jagoan silat dari pihak perempuan dan dua jagoan silat dari pihak laki-laki serta juru pantun dari pihak masing- masing baik laki-laki ataupun perempuan. Beberapa tahapan dari prosesi Palang Pintu dapat dibilang cukup menarik. Sebelum rombongan dari pengantin Laki-laki berangkat menuju rumah pengantin perempuan, pengantin Laki-laki harus dilantunkan. Hal ini bertujuan untuk ibadah, karena pernikahan merupakan ibadah yang dianjurkan oleh agama. Beberapa tahapan prose palang pintu disajikan pada Tabel 1.

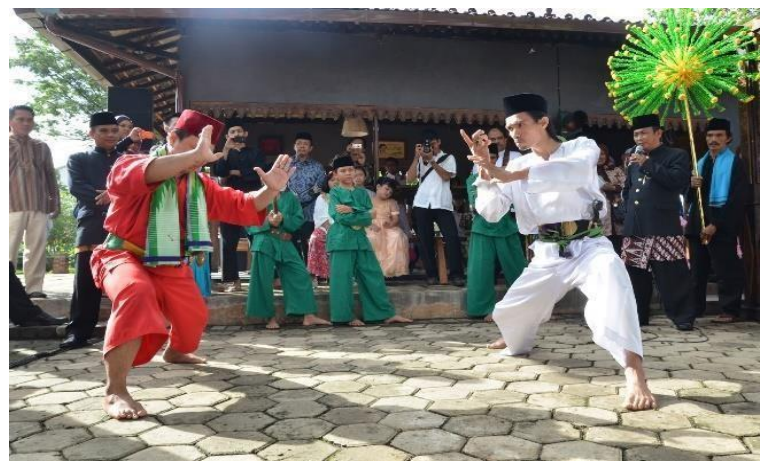

Gambar 1. Palang Pintu Pernikahan 
Tabel 1. Proses Tahapan Palang Pintu

\begin{tabular}{|c|c|c|}
\hline No & $\begin{array}{c}\text { Tahapan proses } \\
\text { Palang Pintu }\end{array}$ & Uraian \\
\hline 1 & $\begin{array}{l}\text { Mengucapkan } \\
\text { salam pembuka } \\
\text { dari kedua } \\
\text { mempelai }\end{array}$ & $\begin{array}{l}\text { Sebelum melakukan salam pembuka, manten laki-laki mendekati } \\
\text { wilayah perempuan dengan diiringi petasan yang akan dipasang. } \\
\text { Ini membuktikan bahwa keberadaan calon besan sudah } \\
\text { mendekati tempat mempelai perempuan. Salam dimulai dari } \\
\text { mempelai wanita dan menanyakan Maksud kedatangan dari } \\
\text { mempelai pria }\end{array}$ \\
\hline 2 & Adu Pantun & $\begin{array}{l}\text { Selanjutnya adalah adu Pantun antar kedua mempelai ini } \\
\text { menanyakan kesiapan mempelai Laki-laki untuk menyanggupi } \\
\text { beberapa syarat yang telah diajukan oleh lawan mempelai. } \\
\text { Syaratnya yaitu adu pukul atau silat dan mengaji serta pantun } \\
\text { yang disajikan dalam bentuk nasehat kedua mempelai. }\end{array}$ \\
\hline 3 & Adu Pukul & $\begin{array}{l}\text { Pada tahapan ini mempelai laki-laki diuji dengan kesanggupan } \\
\text { yaitu memberikan beberapa atraksi bela diri guna menuntaskan } \\
\text { salah satu syarat yang sudah ditetapkan oleh mempelai } \\
\text { perempuan dan dilaksanakan dalam bentuk Palang Pintu. }\end{array}$ \\
\hline 4 & $\begin{array}{l}\text { Pembacaan ayat } \\
\text { suci al-quran atau } \\
\text { mengaji }\end{array}$ & $\begin{array}{l}\text { Sesudah menyelesaikan syarat yang pertama, ujian yang harus } \\
\text { dilakukan adalah membaca ayat suci alqur'an. Di simbolkan } \\
\text { bahwa pembacaan ayat suci alqur'an ini memiliki makna dimana } \\
\text { pengantin laki-laki nantinya menjalankan segala ketentuan } \\
\text { dengan ajaran agama Islam }\end{array}$ \\
\hline 5 & $\begin{array}{l}\text { Pelantunan } \\
\text { sholawat dustur }\end{array}$ & $\begin{array}{l}\text { Ketika kedua syarat tersebut dituntaskan maka Palang pintu } \\
\text { terbuka dan mempelai laki-laki beserta rombongannya } \\
\text { dipersilahkan masuk dan menyegerakan ijab qabul (akad). } \\
\text { Lantunan sholawat dustur yang dilakukan laki-laki apabila ingin } \\
\text { mempelai wanita tersebut memiliki kemuliaan hati serta } \\
\text { kesabaran dalam berumah tangga. }\end{array}$ \\
\hline
\end{tabular}

Geertz (dalam Sobur, 2009) melaporkan kalau arti cuma bisa ditaruh dalam simbol. Seluruh simbol, baik perkata yang terucapkan, suatu objek semacam suatu bendera, sesuatu gerak badan semacam melambaikan tangan, suatu tempat semacam masjid ataupun gereja, ataupun sesuatu kejadian semacam pernikahan, ialah bagian- bagian sesuatu sistem simbol. Simbol merupakan objek ataupun kejadian yang apa juga yang menunjuk pada tempat.

Pada pelaksanaannya, prosedur acara pernikahan memiliki kesamaan terhadap wilayah Betawi yang lainnya. semacam di Jakarta Barat, Timur, Utara, Selatan dan Pusat. Alat-alat yang dipersiapkan yang nantinya digunakan dalam acara pernikahan nantinya adalah Petasan, Kembang Kelapa, ketimpring, rebana, golok, sirih dare, seragam anggota, serta toya yaitu tongkat Panjang. Namun tidak semua alat-alat dapat digunakan seperti toya, dandang, sirih dare serta rebana ketimpring tidak lagi ditemui di wilayah Tanjung Barat. Sebab untuk mempersingkat waktu dalam mempersiapkan berbagai jenis peralatan. 
Tabel 2. Indikator Objek pada Proses Palang Pintu

\begin{tabular}{|c|c|c|}
\hline No & $\begin{array}{l}\text { Tahapan } \\
\text { proses Palang } \\
\text { Pintu }\end{array}$ & Uraian \\
\hline 1 & Kembang Api & $\begin{array}{l}\text { Kembang Api ini memberi makna mengenai informasi atau kabar } \\
\text { kepada mempelai perempuan dan para tetangganya bahwa mempelai } \\
\text { laki-laki sudah beranjak jalan dan mendekati wilayah pengantin } \\
\text { perempuan. }\end{array}$ \\
\hline 2 & $\begin{array}{l}\text { Kembang } \\
\text { Kelapa }\end{array}$ & $\begin{array}{l}\text { Kembang kelapa memiliki makna yaitu mengacu pada sejarah dan } \\
\text { kegunaan Pohon kelapa mulai dari akar, batang, daun hingga buah } \\
\text { kelapa itu sendiri. Dengan harapannya bahwa mempelai laki-laki dan } \\
\text { senantiasa menjalankan kehidupan yang membawa keberkahan } \\
\text { berumah tangganya kelak. }\end{array}$ \\
\hline 3 & Adu Silat & $\begin{array}{l}\text { Para jawara Betawi ini memiliki makna bahwa setiap orang Betawi } \\
\text { khususnya laki-laki siap }\end{array}$ \\
\hline 4 & $\begin{array}{l}\text { Rombongan } \\
\text { Marawis }\end{array}$ & $\begin{array}{l}\text { Tim ini ditandai sebagai makna dimana palang pintu sudah terbuka } \\
\text { dan ajang hiburan sekaligus proses akhir dari tradisi pernikahan adat } \\
\text { Betawi. }\end{array}$ \\
\hline 5 & $\begin{array}{l}\text { Pelantunan } \\
\text { sholawat } \\
\text { dustur }\end{array}$ & $\begin{array}{l}\text { Ketika kedua syarat tersebut dituntaskan maka Palang pintu terbuka } \\
\text { dan mempelai laki-laki beserta rombongannya dipersilahkan masuk } \\
\text { dan menyegerakan ijab qabul (akad). Lantunan sholawat dustur yang } \\
\text { dilakukan laki-laki apabila ingin mempelai wanita tersebut memiliki } \\
\text { kemuliaan hati serta kesabaran dalam berumah tangga. }\end{array}$ \\
\hline
\end{tabular}

Penanda simbol berikutnya bagi Melinda \& Paramitha (2018) meliputi suatu tempat. Pada saat berlangsungnya prosesi palang pintu yang diawali di depan pintu masuk ataupun pagar dini tempat mempelai wanita perihal ini bermakna semacam tujuan dini kehadiran yang tetap berikan salam serta mengantarkan iktikad dan tujuan kedatangan nya. Berkaitan dengan hal tersebut dapat memunculkan fakta bahwa perilaku masyarakat Betawi menjunjung tinggi kesopanan antar sesama. Dalam konteks pernikahan, pemilihan tempat diselenggarakannya proses Palang Pintu adalah di tempat mempelai Perempuan yang menunjukan bahwa Etnis Betawi menganut budaya patriarki sehingga mempelai lai-laki wajib mendatangi tempat mempelai wanita dengan bentuk segala bentuk penghormatan kepada mempelai perempuan.

Penanda simbol yang terakhir meliputi sesuatu kejadian dalam proses Palang Pintu sangat menempel pada kejadian perkawinan. Bersumber pada wawancara dengan Aat Sudrajat berkata kalau proses palang pintu suatu tes yang diberikan kepada mempelai Lakilaki buat menyelesaikan 2 syaratnya ialah adu silat serta membaca al- quran. Tetapi bersamaan berkembangnya era palang pintu tidak cuma digunakan pada kejadian perkawinan saja, namun telah dapat digunakan pada kegiatan kenegaraan ataupun menyongsong tamu negeri apalagi pantun yang digunakan juga memakai bahasa Inggris. Sehingga dari segi gunanya juga telah tumbuh serta perihal tersebut jadi sesuatu kebanggaan untuk warga Betawi

\subsection{Nilai-Nilai Tradisi Palang Pintu dalam Konteks Islam}

Kearifan lokal yang diterapkan oleh masyarakat Betawi sangatlah mendalami yang kemudian menjadi budaya yang memiliki berbagai macam warna dan hal-hal yang menarik. Dalam tradisi palang pintu memiliki unsur agama yang pekat dalam budaya Betawi yang tidak terlepas dari kedatangan agama islam kepada masyarakat Betawi. Budaya timur tengah dalam hal ini menjadi dominasi dalam masyarakat Betawi, Namun di dalamnya ada warna lain seperti 
budaya Tionghoa, dan budaya yang lainnya berada di Kawasan masyarakat Betawi. Semua budaya tersebut mewarnai dimensi religius dan sosial dalam tatanan kehidupan Betawi.

Budaya Masyarakat Betawi ini sebagai salah satu budaya yang hampir tidak bisa dipisahkan dari Agama Islam. Hal tersebut sudah melekat dalam kebudayaan masyarakat Betawi yang terlihat dalam berbagai macam serangkaian kegiatan kebudayaan masyarakat Betawi dalam menjalani kehidupannya sehari-hari. Nilai-nilai islami yang didapatkan merupakan implementasi dari filosofis masyarakat Betawi. Secara sosio-kultur, keberadaan etnik Betawi di tengah-tengah berbagai macam budaya yang masuk ke daerah ibu kota yang membuat masyarakat Betawi senantiasa menjaga dan melestarikan tradisi secara turun temurun. Dalam kehidupan yang sekarang, menghilangkan serta menghancurkan tradisi tersebut dapat menimbulkan beban psikologis. Maka hal ini sebagai masyarakat Betawi yang baik nantinya anak dan cucu cucu mereka mampu merawat dan menjaga serta melestarikan budaya yang sudah lama ini karena budaya Betawi tidak terlepas dari nilai-nilai ajaran Islam.

Tradisi yang dilakukan oleh masyarakat Betawi dalam acara pernikahan memuat nilainilai religius di dalamnya yang berhubungan dengan ajaran Islam. Hal tersebut dijelaskan dalam beberapa aspek dibawah ini, yaitu:

\section{Mengamalkan nilai-nilai yang diajarkan Nabi Muhammad SAW}

Tradisi ini ini memiliki nilai-nilai agamis yang saat ini masih di lestarikan dengan memuliakan Nabi Muhammad SAW melalui pembacaan Shalawat. Pada saat pengantin Lakilaki mendatangi kediaman mempelai perempuan dengan beriringan membawa shalawat nabi dengan menggunakan rebana dan dilanjutkan dengan pembacaan Sike yakni pembacaan ayat suci Al-Qur'an dan Shalawat Nabi sebagai simbol kesiapan mental dan fisik serta rohani mempelai Laki-laki dan wanita. Dalam sejarahnya kehidupan budaya Betawi yang tergambar dalam tradisi palang pintu dimana keimanan seseorang tidak hanya beriman dengan Allah SWT tetapi juga mencintai dan mengimani Rasullulah SAW.

\section{Ikatan Kekeluargaan (Silaturahmi)}

Wujud kearifan lokal yang masih terjaga di Era Globalisasi. Berbagai macam karakteristik masyarakat bangsa Indonesia merupakan suatu sikap sosial yang diterapkan melalui ikatan silaturrahmi. Mereka berkumpul menjadi satu dalam dalam tujuan yang sama. Orang-orang datang berkumpul serta diarahkan terhadap pengajaran yang selalu mengingat kepada allah SWT sebagai rasa syukur. Nilai yang tercantum di dalam tradisi budaya lokal khususnya masyarakat Betawi tersebut mengidentifikasikan bahwa ikatan antara manusia dengan Tuhannya hablu min allah wajib dengan ikatan manusia dengan sesama manusia hablum minannas. Bagi Khamad (dalam Habibullah, 2018) yang tercantum dalam suatu budaya tersebut dan kearifan religius yang terdapat implementasi kearifan Ilahi yang berwajah genin serta lokal.

\section{Melindungi Hal yang berharga}

Dalam hal melindungi diri ini dilakukan dengan berbagai cara salah satunya adalah dengan bertarung atau bela diri untuk melindungi orang yang berharga dalam kehidupannya. Namun dalam hal melindungi diri ada hal yang dilarang oleh agama, yaitu membunuh. Perihal hal ini dilarang dikarenakan dapat mengganggu jiwa manusia. Disimbolkan dengan silat 
ataupun palang pintu dengan metode berkelahi. Anak laki-laki Betawi biasanya sudah diajarkan ilmu bela diri sejak kecil. Silat merupakan salah satu hal yang dapat dilakukan untuk melindungi diri karena pada dasarnya selain menjadi ilmu yang baik untuk diterapkan juga menjadi antisipasi apabila ada orang jahat yang ingin melukai dan membahayakan baik diri kita maupun keluarga.

4. Sopan Santun

Tradisi Palang Pintu diwarnai dengan adegan berpantun dari sepasang jawara pengantin kedua belah pihak. Salah satu indikator yang menjadi keunikan dari budaya Betawi selain lewat nilai gotong royong nya adalah lewat Bahasa atau percakapan. Masyarakat Betawi biasanya memiliki logat yang disimbolkan "E" di dalamnya sehingga secara spontan memiliki karakteristik yang unik dalam berbicara. Dalam adegan beradu pantun biasanya salah satu jawara menggunakan kata-kata yang jenaka sehingga secara Dengan kata lain, pantun mempunyai estetika dalam hal berbicara dalam kegiatan beradu pantun yang memberikan nuansa humor dan menjadi bukti diri masyarakat Betawi. Pantun dalam budaya Betawi tidak hanya dalam tradisi palang pintu saja namun terdapat pula dalam kegiatan tamu yang berkunjung.

\section{Simpulan}

Masyarakat Betawi merupakan masyarakat yang memiliki karakteristik unik sebagai salah satu etnis di dalam kehidupan Daerah Ibu Kota. Masyarakat Betawi pada umumnya kaya akan sejarah dan kebudayaan di dalamnya. Hal ini menjadi suatu ciri khas yang unik karena pada dasarnya kebudayaan Betawi dalam kehidupan sehari-hari mengajarkan nilai-nilai Islam yang berpedoman pada Alqur'an. Sehingga dalam menjalankan kehidupan sehari-hari dengan berlandaskan pedoman nilai-nilai Alqur'an. Palang Pintu merupakan salah satu budaya masyarakat Betawi dengan akulturasi kebudayaan islam di dalamnya dalam prosesi perkawinan masyarakat Betawi pada umumnya. Budaya tersebut mengandung nilai-nilai religius di dalamnya, sehingga dalam pelaksanaannya memerlukan beberapa tahapan yang sakral sehingga unsur budaya dan religiusnya bisa diamalkan dan dilestarikan turun temurun.

\section{Daftar Rujukan}

Aisya, S. (2016). Struktur Teks, Konteks Pertunjukan, dan Ajaran Islam Pada Palang Pintu Pada Pernikahan Adat Betawi. Arkhais-Jurnal Ilmu Bahasa dan Sastra Indonesia, 7(1), 25-28.

Anggito, A., \& Setiawan, J. (2018). Metodologi penelitian kualitatif. CV Jejak (Jejak Publisher).

Batawi, A. \& Ali, Z. (2012). 1500 Pantun Betawi. Jakarta: Nus Printing

Chaer, A. (2012). Foklor Betawi: Kebudayaan dan Kehidupan Orang Betawi. Jakarta: Masup Jakarta

Devi, R. (2013). Tradisi Buka Palang Pintu: Transformasi Tradisi Upacara Menuju Komoditas. dalam Jurnal Fisip UI.

Melinda, A., \& Paramita, S. (2019). Makna Simbolik Palang Pintu Pada Pernikahan Etnis Betawi di Setu Babakan. Koneksi, 2(2), 218-225.

Paramita, S. (2019). Pergeseran Makna Budaya Ondel-Ondel Pada Masyarakat Betawi Modern. Jurnal Bakti Masyarakat Indonesia, 1(1).

Purbasari, M. (2010). Indahnya Betawi. Jurnal Humaniora 1(1), 4. 